\title{
The Self-Perceived Subject-Specific Professional Competencies of Slovenian Physical Education Teachers in Different Working Environments
}

\author{
Marjeta Kovač ${ }^{1}$, Bojan Leskošek ${ }^{2}$, Gregor Jurak ${ }^{1}$, Miloš Tul $^{3}$ \\ ${ }^{1}$ Department for Pedagogy and Didactics in Sport, Faculty of Sport, University of Ljubljana, Ljubljana, Slovenia \\ ${ }^{2}$ Department for Natural Science in Sport, Faculty of Sport, University of Ljubljana, Ljubljana, Slovenia \\ ${ }^{3}$ State Scientific High School France Prešeren, Trieste, Italy
}

\begin{abstract}
A B S T R A C T
This cross-sectional study was designed to analyse the differences in the subject-specific competencies of Slovenian Physical Education (PE) teachers according to their physical working environment. The participants, 681 Slovenian PE teachers, evaluated their professional subject-specific competencies $(n=40)$ on a four-level Likert scale and two factors of their physical working environment (size of sports facilities and their equipment) with a self-administered questionnaire. Differences in their self-perceptions about subject-specific competencies between those working in good conditions and those working in poorer conditions were identified with the Mann-Whitney test for independent samples, and Cliff's delta was used to estimate the size of the differences. The results show that higher perceptions of subject-specific competencies of PE teachers are mainly affected by the equipment of sports facilities, not their size; therefore, local communities and the state should ensure that all schools have roughly equal well-equipped sports facilities.
\end{abstract}

Key words: teachers, competencies, Physical Education, sports facilities, size, equipment

\section{Introduction}

The European Commission has indicated that teachers and, in particular, their competencies are attributed a crucial role in fulfilling quality education, while teachers' competencies have powerful effects on student achievement ${ }^{1}$. The term 'competence' involves tacit and explicit knowledge, cognitive and practical skills, as well as motivation, beliefs, value orientations and emotions ${ }^{2}$. While teachers need a deep knowledge of how to teach their specific subjects ${ }^{1}$, their beliefs about their capabilities to produce given accomplishments in a specific task also determine the quality of teaching and regulate their effort ${ }^{3}$. Self-efficacy is important because it helps with teacher motivation and persistence to accomplish desired objectives, as well as in coping and managing negative events ${ }^{3}$. Social cognitive theory affirms the positive and strong correlation between teachers' beliefs in their self-efficacy and teaching practice ${ }^{4}$. Teachers who expect to be successful at teaching are likely to put more effort into preparing, conducting, and evaluating their lessons, which tends to make them more effective than their colleagues ${ }^{4}$.

The European educational network Eurydice has divided teachers' competencies into general (universal or subject-independent) and specific ones closely related to an individual subject area ${ }^{5}$. Both types should be transferable and available for use in various situations, not solely in the context in which they were acquired. Subject-specific competencies of Physical Education (PE) teachers were defined in the Aligning a European Higher Education Structure and Sport Science (AEHESIS) project, which was created to unify educational programmes in sports at the European level ${ }^{6}$. The competencies of PE teachers and PE student teachers from different European countries have been studied ${ }^{7-17}$. Research studies show that PE teachers highly valued their own pedagogic and didactic knowledge and understanding of health aspects of physical activity. However, they feel insufficiently competent in some general areas, such as the use of information and communications technology, communication in foreign languages, and working with children with special needs, migrant children, and Roma $a^{7,9,12-15}$. Furthermore, various researchers have found that the PE teachers' perception of their competencies is influenced by the teacher's gender $^{11,12,16,17}$, work experience ${ }^{11,12,16}$, and the level of schooling at which they teach ${ }^{12}$. Since teachers' work, 
well-being, and job satisfaction also depend on the working conditions $^{18-21}$, it would be interesting to determine how competent $\mathrm{PE}$ teachers feel if they are teaching in different working environment.

The phrase 'working conditions' refers to the working environment and aspects of an employee's terms and conditions of employment ${ }^{22}$. The school working environment can be understood as resulting from a dynamic relationship between different physical and social elements that constitute the teaching and learning conditions ${ }^{22}$. The working environment positively affects teachers' job satisfaction $^{18-21}$ and students' achievements ${ }^{18,22}$; it is also fundamental to good-quality $\mathrm{PE}^{23,24}$ and should include safe, healthy, and protective physical environments for students and teachers ${ }^{20,22,24}$.

$\mathrm{PE}$ is a subject in which the child's body and his/her physical activity are the focus of curricular learning outcomes $^{23}$. High quality PE is the most effective means of providing all children and youth with the skills, attitudes, values, knowledge, and understanding for lifelong participation in society ${ }^{24}$. Therefore, $\mathrm{PE}$ is included in all national school systems as a vital part of children's development ${ }^{25}$. However, national curriculum documents, Physical Education teacher education programmes and material conditions (the quality and quantity level of provision of facilities and equipment) for implementing $\mathrm{PE}$ vary considerably both between ${ }^{25}$ and within countries $^{26,27}$. Most school subjects are taught in classrooms whose size and equipment are determined according to the purpose of the subject taught in them. Hence, PE is traditionally taught in gyms (a special sports facility to provide PE classes and other extra-curricular sports activities) or other sports facilities (dance halls, swimming pools, outside playgrounds, fitness studios, etc.). The suitability of the physical teaching environment in $\mathrm{PE}$ is determined by many factors: the size of the gym and its quality arrangement (quality of sports floor, lighting, acoustic characteristics of the gym, ventilation), and the amount and quality of sports equipment (their suitability for the developmental stage of the pupils, selection of sports equipment and tools according to the offered contents, their distribution in the sports facility, storage and functionality in terms of frequency of their use $)^{26}$.

Research studies also show that the physical environment in which exercise occurs has a consistently positive effect on people's physical activity ${ }^{28,29}$. Thus, Mahar ${ }^{30}$ reports that children's level of physical activity is related to the conditions in which they can be active. At the same time, appropriate environments reduce the risk of injuries and health problems of PE teachers ${ }^{31-33}$ and stu$\operatorname{dents}^{34}$.

In Slovenia, the vast majority of primary school gyms are owned by local communities, as they are the founders of primary schools, and the ownership of secondary school gyms is very diverse, as they are owned by the state, local communities, associations, or private individuals from whom schools hire them ${ }^{26}$. Understandably, different stakeholders bear different investment burdens in the construction and maintenance of gyms ${ }^{26}$. Furthermore, research on the material conditions of schools for conducting PE classes has shown that the size of Slovenian gyms, their age and equipment are very diverse ${ }^{26}$; therefore, teachers work in different teaching and learning conditions.

The Slovenian curriculum for PE in primary school ${ }^{35}$ states: 'Every student needs $20 \mathrm{~m}^{2}$ of space during PE practice, which in exceptional circumstances should not be less than $10 \mathrm{~m}^{2}$. Premises, tools and equipment must comply with safety, hygiene and health principles, so that they provide students and teachers with safe and pleasant exercise.' Each school should have the equipment for different sports as listed in the manual for PE teachers ${ }^{36}$. The number of students in the training group is determined by The Rules on Norms and Standards for the Implementation of the Primary School Programme ${ }^{37}$ and The Rules on Norms and Standards for the Implementation of Educational Programmes in the Field of Secondary Education ${ }^{38}$. The former provides up to 28 students from $1^{\text {st }}$ to $5^{\text {th }}$ grades and a maximum of 20 students from $6^{\text {th }}$ to $9^{\text {th }}$ grades, while the second usually provides for 20 students in PE classes in various secondary school programmes.

Slovenian PE teachers are very satisfied with their current professional position ${ }^{39}$ and perceive their subject-specific competencies high ${ }^{11,12,14}$. Furthermore, it is known that professionals who feel competent have more intrinsic motivation in their jobs ${ }^{3}$. Since quality PE is also significantly influenced by highly competent teachers and their teaching, as well as the teaching and learning environment in which they work ${ }^{24}$, we conducted a study to evaluate the differences between the self-perceived subject-specific professional competencies of Slovenian $\mathrm{PE}$ teachers in different working environments.

\section{Materials and Methods}

As in previous studies ${ }^{10,12}$, a self-administered questionnaire was constructed. The questionnaire consisted of four parts: i) demographic (gender, length of work experience, age, teaching level); ii) general competencies (36 items), iii) subject-specific competencies (40 items), and iv) working environment (size of gyms and other sports facilities, quantity and quality of sports equipment, sports technology, number of students in the group). For the purpose of this paper, only the self-perception of subject-specific competencies and two factors of working environment: gyms size (GS) and equipment quality (EQ) are used.

Subject-specific competencies include specific aspects of the field of PE, such as knowledge of social sciences, biological and physiological aspects of PE; knowledge of training theory; mastering pedagogical skills; didactic skills related to the teaching of $\mathrm{PE}$ in the narrower (demonstrations of movement skills and methodological procedures) and broader meanings (interdisciplinary teaching, use of modern 
teaching technology, evaluation of the learning process). Teachers reported their current levels of competencies on a four-level scale (1-completely incompetent, 2-less competent, 3-competent, and 4-highly competent). Teachers also evaluated two factors of working environments: i) GS (1-we do not have our own sports facilities, we teach in rented premises; 2-own sports facilities, but too small in terms of the number of students; 3-large enough own sports facilities; 4-above-standard large own sports facilities); and ii) EQ (1-insufficient equipment, poor quality; 2-sufficient equipment, but of poor quality; 3-good equipment; 4-excellent equipment). For a better overview of results, the frequencies of statements about working environments were joined for each factor into two groups by combining Answers 1 and 2 (GS-: those teaching in rented premises or in their own sports facilities, but too small in terms of the number of students; EQ-: those teaching in sports facilities with insufficient equipment or with poor quality equipment) and 3 and 4 (GS+: those teaching in their own large enough or even above-standard large sports facilities; EQ+: those teaching in sports facilities with good or excellent equipment).

This study was approved in advance by the Ethics Committee of the University of Ljubljana. The questionnaire was sent to all Slovenian primary $(n=449)$ and secondary schools $(n=137)$ by regular mail and invited PE teachers to complete it. Teachers were informed about the objectives of the study and the voluntary and anonymous nature of their participation.

\section{Statistics}

The data were analysed with IBM SPSS Statistics 23.0 software. First, the basic statistics of variable distribution were calculated. Then, the difference between the subsamples (GS+ and GS-; EQ+ and EQ-) was examined using the Mann-Whitney test for independent samples, taking into account a 5\% risk rate for error. Finally, Cliff's delta was used to estimate the size of the differences between groups.

\section{Results}

Before administration, the questionnaire was qualitatively validated for content by a group of $22 \mathrm{PE}$ teachers (10 male and 12 female) of different ages, amounts of working experience, and working at different teaching levels. The original questionnaire was shortened slightly, as per the recommendations of the validation group. The entire questionnaire has a high degree of reliability (Cronbach's alpha=0.97), while the values of individual questionnaire segments vary between 0.62 and 0.92 .

The sample, 681 Slovenian PE teachers, consisted of 408 males (59.9\%) and 273 females (40.1\%); 439 (64.5\%) participants were employed at primary schools $\left(6^{\text {th }}\right.$ to $9^{\text {th }}$ grades $), 216(31.7 \%)$ participants at secondary schools $\left(10^{\text {th }}\right.$ to $13^{\text {th }}$ grades), and the remaining participants were employed elsewhere ( $1^{\text {st }}$ to $5^{\text {th }}$ grades, project work). The sample represents approximately $53 \%$ of the entire population of PE teachers in Slovenia. Almost half of the participants have been teaching for more than 20 years $(n=307,45.1 \%)$; the remaining participants are almost equally distributed in the following groups: from 11 to 20 years of working experience $(\mathrm{n}=189,27.8 \%)$, and up to 10 years of working experience $(n=185,27.1 \%)$.

First, we compared the perception of the competencies of teachers who teach in rented or in their own but too small school gyms (GS-: n=304, 44.6\%) and teachers who teach in sufficiently large or even above-standard school gyms (GS+: $n=371,54.5 \%$; did not respond $n=6,0.9 \%$ ). Second, the perception of competencies between teachers who teach in insufficiently or barely sufficiently equipped gyms (EQ-: n=269, 39.5\%) and teachers who teach in wellor even excellently equipped gyms $(\mathrm{EQ}+: \mathrm{n}=412,60.5 \%)$ is compared.

According to GS, the two subgroups differ statistically significantly only in two subject-specific competencies: understanding physiological aspects of physical activity and sport (Me GS-=3.44, Me GS+=3.30, p=0.045) and understanding biomechanical aspects of sport (Me GS$=3.08$, Me GS+=2.97, $\mathrm{p}=0.043)$. Higher competencies have

TABLE 1

THE DIFFERENCE BETWEEN THE PERCEPTIONS OF SUBJECT-SPECIFIC COMPETENCIES ACCORDING TO THE GYM'S SIZE (GS)

\begin{tabular}{lcccccc}
\hline \multicolumn{1}{c}{ Competencies } & M_W_p & Me GS- IQR GS- & Me GS+ & IQR GS+ & C_d \\
\hline Understanding social importance of sport & 0.512 & 3.39 & 1.05 & 3.44 & 1.06 & -0.03 \\
Understanding cultural aspects of sport & 0.600 & 3.17 & 0.99 & 3.14 & 0.96 & 0.02 \\
Understanding philosophical aspects of sport & 0.548 & 2.72 & 1.20 & 2.68 & 1.27 & 0.03 \\
Understanding historical aspects of sport & 0.307 & 3.01 & 0.90 & 2.96 & 0.86 & 0.04 \\
Understanding social circumstances in physical education (PE) lessons & 0.099 & 3.29 & 1.03 & 3.21 & 0.98 & 0.07 \\
Understanding health aspects of physical activity and sport & 0.402 & 3.67 & 0.98 & 3.62 & 1.00 & 0.03 \\
Understanding anatomical-functional aspects of sport & 0.204 & 3.46 & 1.05 & 3.37 & 1.05 & 0.05 \\
Understanding physiological aspects of physical activity and sport & $0.045^{*}$ & 3.44 & 1.06 & 3.30 & 1.04 & 0.08 \\
Understanding biomechanical aspects of sport & $0.043^{*}$ & 3.08 & 1.08 & 2.97 & 0.91 & 0.08 \\
Understanding psychological aspects of sport & 0.094 & 3.27 & 1.00 & 3.20 & 1.01 & 0.07 \\
\hline
\end{tabular}


TABLE 1

Continued...

\begin{tabular}{|c|c|c|c|c|c|c|}
\hline Competencies & M_W_p & Me GS- & IQR GS- & Me GS+ & IQR GS+ & C_d \\
\hline Understanding physical and motor development of children and youth & 0.997 & 3.50 & 1.04 & 3.50 & 1.04 & 0.00 \\
\hline Understanding media influence on sport & 0.435 & 2.93 & 1.09 & 2.90 & 1.00 & 0.03 \\
\hline Understanding financial flow in sport & 0.552 & 2.42 & 1.23 & 2.48 & 1.24 & -0.02 \\
\hline Understanding theory of practising sport & 0.134 & 3.22 & 1.04 & 3.15 & 1.01 & 0.06 \\
\hline Understanding PE curriculum & 0.590 & 3.68 & 0.99 & 3.69 & 0.96 & -0.02 \\
\hline Qualification for setting goals according to curriculum & 0.784 & 3.36 & 1.08 & 3.36 & 1.05 & -0.01 \\
\hline Understanding general didactics of PE process & 0.496 & 3.38 & 1.04 & 3.34 & 1.03 & 0.03 \\
\hline Qualification for diagnosing and composing status analysis & 0.684 & 3.08 & 0.81 & 3.07 & 0.91 & 0.02 \\
\hline $\begin{array}{l}\text { Qualification for planning a process according to status analysis and } \\
\text { curriculum }\end{array}$ & 0.905 & 3.21 & 1.02 & 3.19 & 0.94 & 0.00 \\
\hline Understanding methodical ways in teaching motor skills from the curriculum & 0.898 & 3.57 & 1.02 & 3.56 & 1.01 & 0.01 \\
\hline $\begin{array}{l}\text { Understanding methodical ways in teaching skills that are not a part of the } \\
\text { curriculum }\end{array}$ & 0.399 & 3.00 & 0.77 & 3.03 & 0.85 & -0.03 \\
\hline Qualification for demonstrating skills that are a part of curriculum & 0.724 & 3.39 & 1.06 & 3.36 & 1.05 & 0.01 \\
\hline Qualification for demonstrating skills that are not a part of curriculum & 0.653 & 2.98 & 0.80 & 3.00 & 0.91 & -0.02 \\
\hline Ability to use different teaching methods and forms of teaching PE & 0.507 & 3.57 & 1.03 & 3.50 & 1.02 & 0.03 \\
\hline $\begin{array}{l}\text { Qualification for pedagogical management of class in PE (conflict manage- } \\
\text { ment, respect for diversity and ethics). }\end{array}$ & 0.086 & 3.52 & 1.07 & 3.37 & 1.04 & 0.07 \\
\hline Understanding how to use different pedagogic strategies in $\mathrm{PE}$ & 0.635 & 2.87 & 1.06 & 2.89 & 0.93 & -0.02 \\
\hline Respecting principles of inclusion, individualisation and differentiation & 0.885 & 3.10 & 0.91 & 3.10 & 0.77 & -0.01 \\
\hline Recognising sport-talented students and guidance & 0.781 & 3.44 & 1.06 & 3.41 & 1.06 & 0.01 \\
\hline Qualification for encouraging students to be sport active in free time & 0.842 & 3.50 & 1.04 & 3.51 & 1.07 & 0.01 \\
\hline $\begin{array}{l}\text { Qualification for encouraging students' learning in an instructive and } \\
\text { creative way }\end{array}$ & 0.740 & 3.16 & 0.90 & 3.15 & 0.85 & 0.01 \\
\hline Qualification for encouraging creativity in finding solutions to motor tasks & 0.365 & 3.12 & 0.89 & 3.08 & 0.84 & 0.04 \\
\hline Qualification for efficient conveying of theoretical contents in PE lessons & 0.399 & 3.21 & 1.02 & 3.16 & 0.97 & 0.03 \\
\hline Qualification for cross-curricular issues & 0.824 & 2.97 & 0.83 & 2.96 & 0.80 & 0.01 \\
\hline Qualification for working with modern teaching technology in PE & 0.604 & 2.80 & 1.09 & 2.83 & 1.04 & -0.02 \\
\hline $\begin{array}{l}\text { Understanding the importance of continuous professional development for PE } \\
\text { teacher }\end{array}$ & 0.138 & 3.48 & 1.09 & 3.35 & 1.05 & 0.06 \\
\hline $\begin{array}{l}\text { Organisational skills and knowledge for the implementation of school and } \\
\text { extracurricular programmes }\end{array}$ & 0.757 & 3.44 & 1.11 & 3.38 & 1.06 & 0.01 \\
\hline Qualification for encouraging personal progress of a student & 0.721 & 3.32 & 1.04 & 3.34 & 1.04 & -0.01 \\
\hline Qualification for different ways of assessment and grading knowledge in PE & 0.412 & 3.27 & 1.04 & 3.31 & 1.05 & -0.03 \\
\hline $\begin{array}{l}\text { Qualification for formation and conveying of feedback information to students } \\
\text { and parents }\end{array}$ & 0.236 & 3.35 & 1.06 & 3.27 & 0.99 & 0.05 \\
\hline Qualification for evaluation of own pedagogical work in PE & 0.979 & 3.24 & 1.01 & 3.24 & 1.02 & 0.00 \\
\hline
\end{tabular}

been reported by teachers who teach in too small or rented gyms (Table 1).

Several differences in the perception of actual subject-specific competencies were shown between the two groups, which were formed according to the EQ of gyms. Statistically significant differences between both groups were shown in 11 out of 40 competences. In all 11, teachers who teach in well-equipped gyms $(\mathrm{EQ}+)$ evaluated their competencies statistically significantly higher. The specif- ic competencies that separate the two groups can be combined into two major content sets:

a) some social science aspects of sport and PE, namely: understanding social importance of sport (Me EQ-=3.35, Me EQ+=3.48, $\mathrm{p}=0.007)$, understanding cultural aspects of sport (Me EQ-=3.13, Me EQ+=3.25, p=0.023), understanding historical aspects of sport (Me EQ-=2.88, Me $\mathrm{EQ}+=3.04, \mathrm{p}=0.014)$, and understanding financial flow in sport $(\mathrm{Me} E \mathrm{E}-=2.41, \mathrm{Me} \mathrm{EQ}+=2.54, \mathrm{p}=0.035)$. 
b) some didactic and pedagogical aspects of PE: understanding $\mathrm{PE}$ curriculum (Me EQ-=3.35, Me EQ+=3.64, $\mathrm{p}=0.025)$, understanding methodical ways in teaching skills that are not a part of the curriculum (Me EQ $-=2.95$, $\mathrm{Me} \mathrm{EQ}+=3.08, \mathrm{p}=0.026$ ), qualification for demonstrating skills that are not a part of the curriculum (Me EQ $-=2.89$, $\mathrm{Me} \mathrm{EQ}+=3.05, \mathrm{p}=0.012$ ), ability to use different teaching methods and forms of teaching $\mathrm{PE}(\mathrm{Me} \mathrm{EQ}-=3.45$, Me $\mathrm{EQ}+=3.54, \mathrm{p}=0.031)$, understanding how to use different pedagogic strategies in $\mathrm{PE}(\mathrm{Me} \mathrm{EQ}-=2.77, \mathrm{Me} \mathrm{EQ}+=2.89$, $\mathrm{p}=0.034$ ), qualification for encouraging students to be sport active in free time (Me EQ-=3.41, $\mathrm{Me} \mathrm{EQ+=3.52,} \mathrm{p=0.018)}$ and qualification for encouraging personal progress of a student (Me EQ-=3.3, Me EQ+=3.41, p=0.018) (Table 2).

\section{Discussion}

Teachers' beliefs about their self-efficacy determine the quality of teaching and affect student outcomes ${ }^{3-5}$. In addition, teachers' belief systems influence the way they respond to children ${ }^{40}$ and guide their decisions when teaching ${ }^{3,9}$. Therefore, it is important to include the educators' self-evaluations in the examination of PE competencies. We believe that one of the main duties of a responsible PE teacher is the continual and critical self-assessment of their effectiveness.

The main finding of this study is that the working environment can affect $\mathrm{PE}$ teachers' beliefs about their competencies. The results show that the higher perception of

TABLE 2

THE DIFFERENCE BETWEEN THE PERCEPTIONS OF SUBJECT-SPECIFIC COMPETENCIES ACCORDING TO THE EQUIPMENT QUALITY (EQ)

\begin{tabular}{|c|c|c|c|c|c|c|}
\hline Competencies & M_W_p & Me EQ- & IQR EQ- & $\mathrm{Me} \mathrm{EQ+}$ & IQR EQ+ & C_d \\
\hline Understanding social importance of sport & $0.007^{*}$ & 3.35 & 1.17 & 3.48 & 1.09 & -0.11 \\
\hline Understanding cultural aspects of sport & $0.023^{*}$ & 3.13 & 1.27 & 3.25 & 1.23 & -0.09 \\
\hline Understanding philosophical aspects of sport & 0.077 & 2.59 & 1.39 & 2.71 & 1.37 & -0.07 \\
\hline Understanding historical aspects of sport & $0.014^{*}$ & 2.88 & 1.28 & 3.04 & 1.28 & -0.10 \\
\hline Understanding social circumstances in physical education (PE) lessons & 0.418 & 3.28 & 1.22 & 3.31 & 1.18 & -0.03 \\
\hline Understanding health aspects of physical activity and sport & 0.318 & 3.55 & 0.97 & 3.59 & 0.91 & -0.04 \\
\hline Understanding anatomical-functional aspects of sport & 0.135 & 3.38 & 1.17 & 3.45 & 1.11 & -0.06 \\
\hline Understanding physiological aspects of physical activity and sport & 0.767 & 3.38 & 1.19 & 3.39 & 1.15 & -0.01 \\
\hline Understanding biomechanical aspects of sport & 0.263 & 2.97 & 1.34 & 3.05 & 1.30 & -0.05 \\
\hline Understanding psychological aspects of sport & 0.251 & 3.25 & 1.20 & 3.31 & 1.21 & -0.05 \\
\hline Understanding physical and motor development of children and youth & 0.149 & 3.44 & 1.16 & 3.51 & 1.00 & -0.06 \\
\hline Understanding media influence on sport & 0.088 & 2.82 & 1.33 & 2.93 & 1.33 & -0.07 \\
\hline Understanding financial flow in sport & $0.035^{*}$ & 2.41 & 1.40 & 2.54 & 1.35 & -0.09 \\
\hline Understanding theory of practising sport & 0.185 & 3.18 & 1.28 & 3.25 & 1.25 & -0.05 \\
\hline Understanding PE curriculum & $0,025^{*}$ & 3.55 & 0.98 & 3.64 & 0.87 & -0.09 \\
\hline Qualification for setting goals according to curriculum & 0.068 & 3.34 & 1.22 & 3.42 & 1.14 & -0.07 \\
\hline Understanding general didactics of $\mathrm{PE}$ process & 0.067 & 3.34 & 1.18 & 3.43 & 1.11 & -0.07 \\
\hline Qualification for diagnosing and composing status analysis & 0.092 & 3.05 & 1.27 & 3.14 & 1.25 & -0.07 \\
\hline $\begin{array}{l}\text { Qualification for planning a process according to status analysis and } \\
\text { curriculum }\end{array}$ & 0.106 & 3.21 & 1.27 & 3.29 & 1.18 & -0.06 \\
\hline Understanding methodical ways in teaching motor skills from the curriculum & 0.448 & 3.51 & 1.02 & 3.54 & 0.97 & -0.03 \\
\hline $\begin{array}{l}\text { Understanding methodical ways in teaching skills that are not a part of the } \\
\text { curriculum }\end{array}$ & $0.026^{*}$ & 2.95 & 1.22 & 3.08 & 1.25 & -0.09 \\
\hline Qualification for demonstrating skills that are a part of curriculum & 0.389 & 3.37 & 1.18 & 3.41 & 1.14 & -0.03 \\
\hline Qualification for demonstrating skills that are not a part of curriculum & $0.012^{*}$ & 2.89 & 1.30 & 3.05 & 1.26 & -0.10 \\
\hline Ability to use different teaching methods and forms of teaching PE & $0.031^{*}$ & 3.45 & 1.09 & 3.54 & 0.97 & -0.09 \\
\hline $\begin{array}{l}\text { Qualification for pedagogical management of class in PE (conflict manage- } \\
\text { ment, respect for diversity and ethics) }\end{array}$ & 0.415 & 3.42 & 1.16 & 3.45 & 1.11 & -0.03 \\
\hline Understanding how to use different pedagogic strategies in $\mathrm{PE}$ & $0.034^{*}$ & 2.77 & 1.36 & 2.89 & 1.26 & -0.09 \\
\hline Respecting principles of inclusion, individualisation and differentiation & 0.074 & 3.09 & 1.27 & 3.18 & 1.20 & -0.07 \\
\hline Recognising sport-talented students and guidance & 0.079 & 3.38 & 1.20 & 3.46 & 1.10 & -0.07 \\
\hline Qualification for encouraging students to be sport active in free time & $0.018^{*}$ & 3.41 & 1.16 & 3.52 & 1.00 & -0.09 \\
\hline
\end{tabular}


TABLE 2

Continued...

\begin{tabular}{|c|c|c|c|c|c|c|}
\hline Competencies & M_W_p & Me EQ- & IQR EQ- & $\mathrm{Me} \mathrm{EQ}+$ & $\mathrm{IQR} \mathrm{EQ}+$ & C_d \\
\hline $\begin{array}{l}\text { Qualification for encouraging students' learning in an instructive and creative } \\
\text { way }\end{array}$ & 0.055 & 3.15 & 1.23 & 3.25 & 1.17 & -0.07 \\
\hline Qualification for encouraging creativity in finding solutions to motor tasks & 0.101 & 3.08 & 1.26 & 3.17 & 1.23 & -0.07 \\
\hline Qualification for efficient conveying of theoretical contents in PE lessons & 0.324 & 3.20 & 1.26 & 3.25 & 1.22 & -0.04 \\
\hline Qualification for cross-curricular issues & 0.072 & 2.89 & 1.29 & 3.00 & 1.23 & -0.07 \\
\hline Qualification for working with modern teaching technology in PE & 0.067 & 2.71 & 1.33 & 2.82 & 1.27 & -0.08 \\
\hline $\begin{array}{l}\text { Understanding the importance of continuous professional development for PE } \\
\text { teacher }\end{array}$ & 0.067 & 3.36 & 1.20 & 3.45 & 1.13 & -0.07 \\
\hline $\begin{array}{l}\text { Organisational skills and knowledge for the implementation of school and } \\
\text { extracurricular programmes }\end{array}$ & 0.263 & 3.38 & 1.22 & 3.43 & 1.14 & -0.05 \\
\hline Qualification for encouraging personal progress of a student & $0.018^{*}$ & 3.30 & 1.21 & 3.41 & 1.14 & -0.10 \\
\hline Qualification for different ways of assessment and grading knowledge in PE & 0.19 & 3.30 & 1.24 & 3.36 & 1.18 & -0.05 \\
\hline $\begin{array}{l}\text { Qualification for formation and conveying of feedback information to students } \\
\text { and parents }\end{array}$ & 0.197 & 3.32 & 1.20 & 3.38 & 1.14 & -0.05 \\
\hline Qualification for evaluation of own pedagogical work in PE & 0.582 & 3.27 & 1.23 & 3.30 & 1.21 & -0.02 \\
\hline
\end{tabular}

*p<0.05, M_W_p - Mann Whitney test's p-value, Me EQ-- median of insufficiently equipped gyms, IQR EQ--interquartile range for insufficiently equipped gyms, Me EQ+ - median of sufficiently equipped gyms, IQR EQ+ - interquartile range for insufficiently equipped gyms, C_d - Cliff's delta

subject-specific competencies of Slovenian PE teachers is mainly affected by the equipment of sports facilities, not their size. PE teachers teaching in well- or even excellently equipped gyms evaluate some of their competencies $(n=11)$ higher, and those teaching in rented and small gyms have adapted their competencies $(n=2)$ to poorer working conditions.

In Slovenia, every primary school must have a gym $^{41}$; its size is standardised according to the number of students attending each school, and the maximum number of students in the training group is prescribed ${ }^{37,38}$; the PE curriculum also determines the size of the training area per student ${ }^{35}$. The situation is worse in secondary schools founded by the state. Some high schools that were built decades ago and are in city centres have too small gyms, so they rent additional facilities that are not equipped for PE classes (e.g., fitness studios) and are usually distant from the school building ${ }^{26}$. Thus, they do not allow for the optimal implementation of the school programme. Also, in this study, almost half (44.6\%) of Slovenian PE teachers reported teaching in rented or too small school gyms. In doing so, teachers must be very innovative in achieving the curriculum goals, and the choice of teaching content is limited mainly to activities that they can carry out in nature (Nordic walking, running, orientation) or strength development training in rented fitness studios. Consequently, the programmes they offer to students are focused primarily on developing aerobic endurance and strength. Poorer working conditions can affect their motivation to improve their knowledge and skills and adapt their competencies. These are probably the reasons why teachers who teach in such conditions value their knowledge of the physiological and biomechanical aspects of sport higher
(Table 1). Additionally, this higher perception of their own competencies can help them build the motivation for their work and persistence necessary to complete the desired goals of the PE curriculum.

Since self-efficacy is an active and learned system of beliefs, it changes over time $\mathrm{e}^{3,5}$. A stimulating and healthy working environment positively affects the individual, their motivation and promotes further development of competencies $^{20,22,42}$, as also demonstrated by the results of this study. Hardman ${ }^{25}$ reported that the quality and quantity of sport facilities and their equipment can detrimentally affect the quality of PE programmes. Safe and adequate equipment are therefore of great significance to students' educational experiences in PE. Good equipment certainly increases the interest of lessons and enables faster students' learning ${ }^{30}$, and a poor working environment increases the possibility of injuries, both for students $^{34}$ and teachers ${ }^{31-33}$.

A study on the school sports environment in Slovenia ${ }^{26}$ showed that half of teachers assess the equipment of sports halls as poor, especially for gymnastics (47\%) and handball (50\%). For other content, they consider the state of equipment to be good or very good. In this study, almost $60.5 \%$ of teachers reported that their school gyms were well or even excellently equipped. This group more highly values subject-specific competencies in two very important content areas: in the field of social sciences and didactic-pedagogical competencies (Table 2).

For PE teachers, the physical-motor dimension is undoubtedly the most relevant domain in their profession ${ }^{23}$, although one of the most important prerequisites of the future PE teacher is the ability to interact and relate with 
the students from different social and cultural environments ${ }^{24}$. Slovenian PE teachers reported that they feel insufficiently competent when working with children with special needs, migrant children, and Roma ${ }^{11,12,14}$. It seems that teachers who work in better-equipped gym halls perceive higher competencies from social, cultural, and economic aspects of sport. PE teachers identified PE as a place for learning about and through physical activity participation for different groups of children ${ }^{23,24}$. The project 'Advancing key qualifications of disadvantaged young people through sporting activities' pointed out that sport is a mean of the effective socialisation of those children who come from lower socio-economic groups, students with special needs, students with behavioural problems due to their social exclusion, immigrants (in Slovenia mainly from the countries of the former Yugoslavia), and Roma ${ }^{43}$. Their main problems are lack of parental awareness of the importance of physical activity, lack of funding for additional extra-curricular sports activities and, above all, insufficient knowledge of the Slovenian language ${ }^{43}$. For those children, participation in PE lessons in wellequipped gyms probably is not stressful, while the knowledge of the language does not have a significant impact on their performance. Namely, with its physical practices, sport represents a universal 'language' and can play an important role in integrating these children into new social settings ${ }^{43}$.

Many researchers ${ }^{7-9,11-16}$ find that specific didactic knowledge is one of the most important competencies of PE teachers. Today, teaching PE means, first of all, being aware of the dynamics of the educational teaching and learning process ${ }^{9}$. Teachers who work in better-equipped gym halls perceive higher competencies at different levels of pedagogical-didactic behaviour. First of all, they better understand the PE curriculum ( $\mathrm{p}=0.025)$, which probably means that the given conditions allow them to implement most content in the PE curriculum more efficiently. Secondly, teaching in better working conditions is reflected in a higher evaluation of those competencies, regarding the ability to use different teaching methods and forms of teaching PE $(p=0.031)$, understanding methodical ways in teaching skills that are not a part of the curriculum $(p=0.026)$, and their qualification for demonstrating skills that are not a part of the curriculum $(p=0.012)$. The better equipment of the gym probably gives them a feeling of greater certainty in planning the exercise and a much more diverse and interesting creation of learning situations during the PE lessons. Additionally, new sports that are interesting for young people are constantly appearing (e.g., in-line skating, new forms of dance and aerobics, and new non-traditional games, such as T-ball). Hardman ${ }^{25}$ points out that the excessive inclusion of traditional content, which is not particularly related to sports that young people practice in their free time today, is one of the key problems of their lack of interest in regular PE sessions. If $\mathrm{PE}$ teachers attempt to include these sports in regular PE lessons, it requires a competent understanding of methodical ways, their qualification for demonstrating skills to teach this content efficiently, and appropriate sports equipment.

Under good conditions, PE teachers probably spend less time organising the teaching process, so they can spend more time on specific pedagogical approaches $(p=0.034)$. In a time of increased emphasis on academic results and some behavioural problems of students, it is important that $\mathrm{PE}$ teachers believe that they are adequately qualified for the successful pedagogical management of $\mathrm{PE}$ lessons.

Numerous studies demonstrate the extremely important influence of the physical environment on an individual's sports activity ${ }^{28,29}$. In this research, we also find that good teaching conditions allow teachers to feel more competent in encouraging students to be physically active $(p=0.018)$ and to be focused on their personal progress $(p=0.018)$, and thus certainly more easily accomplish the main purposes of $\mathrm{PE}^{24}$.

\section{Conclusion}

Since teachers' beliefs about their competencies determine the quality of teaching ${ }^{3}$, job satisfaction ${ }^{18-21}$, and motivation to improve educational outcomes ${ }^{5,18}$, it is important to investigate what factors affect their competencies. It is known that the teachers' gender ${ }^{11,12,16,17}$, work experience ${ }^{11,12,16}$, and the level of schooling at which they teach ${ }^{12}$, influence their perceptions of their competencies. The results of the present study show the interdependence between a well-equipped learning environment and a higher perception of certain PE teachers' competencies, and, in contrast, the need for a greater teacher's ability to find additional knowledge and adapt their competencies due to a less appropriate working environment. Since a system of beliefs changes over time ${ }^{3,5}$, not only initial teacher education and Physical Education teacher education programmes but also their continuous professional development are highly relevant both for improving educational performance and effectiveness and for enhancing teachers' commitment, identity, and job satisfaction ${ }^{44}$. Teaching staff nowadays also need the competencies to constantly innovate and adapt their own practices. Therefore, continuous professional development programmes should be prepared to show the possibilities of teaching $\mathrm{PE}$ in different working environments and thus develop teachers' competencies.

Teachers are expected to have a high degree of adaptability to the work context ${ }^{5,44}$, in which students should develop new knowledge and skills, while countries should provide the best possible teaching and learning conditions for all schools through appropriate standardisation (size of teaching facilities, prescribed teaching equipment, the maximum number of students in groups). In Slovenia, the size of the gym and the number of students in the training area are regulated by $\mathrm{law}^{37,38,41}$, and the equipment is only recommended $^{36}$. To ensure equality in education for all students and provide more satisfied teachers who perceive 
their competence higher, the state should also standardise the quantity and quality of sports equipment in schools so that students receive a quality implementation of $\mathrm{PE}$ in the most equivalent teaching and learning conditions.

This study has some limitations. We did not examine the concomitant effects of the working environment, teachers' age, and gender on the perception of subject-specific competencies. Another limitation is the considerable differences in the working environments for implementing
PE curricula worldwide ${ }^{25}$; therefore, readers should be careful when generalising findings to different countries.

We believe that this study could partially clarify how the efficacy beliefs of PE teachers originate under different working conditions. Since we did not find research in the literature on the perception of the competencies of $\mathrm{PE}$ teachers in relation to the quality of the working environment, our findings represent the initial starting point for further research.

\section{R E F E R E N C E S}

1. EUROPEAN COMMISSION, Rethinking Education: Investing in skills for better socio-economic outcomes, https://www.cedefop.europa.eu/ en/content/rethinking-education-investing-skills-better-socio-economicoutcomes. - 2. RYCHEN DS, SALGANIK LH, Key Competencies for a Successful Life and a Well-Functioning Society (Hogrefe \& Huber Publishers, Toronto, 2003). - 3. TSCHANNEN-MORAN M, HOY AW, Teach Teach Educ, 23 (2007) 944. doi: 10.1016/j.tate.2006.05.003. - 4. BANDURA A, Psychol Rev, 84 (1977) 191. doi: 10.1037/0033-295X.84.2.191. -5. EUROPEAN COMMISSION, Key Competencies, Survey 5 (Eurydice, Brussels, 2002). - 6. PETRY K, FROBERG K, MADELLA A, TOKARSKY W, Higher Education in Sport in Europe. From labour Market demand to Training Supply (Meyer \& Meyer Sport, London, 2008). - 7. ASUN S, CHIVITE MT, ROMERO MT, Sustainability, 12 (2020) 3812. doi: 10.3390/ su12093812. - 8. CAMPOS MESA MC, RIES F, DEL CASTILLO O, Rev Int Cienc Deporte, 24 (2011) 216. doi: 10.5232/ricyde2011.02405. - 9. CASOLO F, COCO D, FRATTINI G, VAGO P, CASOLO A, JPES, 19 (2019) 1806. doi:10.7752/jpes.2019.s5265. - 10. GALLARDO AM, Electron J Res Educ Psychol, 10 (2006) 469. - 11. KOVAČ M, STARC G, STREL J, JURAK G, Šport, 53 (2005) 2. - 12. KOVAČ M, SLOAN S, STARC G, Eur Phys Educ Rev, 14 (2008) 299. doi:10.1177/1356336X08095668. - 13. ROMERO GRANADOS S, CAMPOS MESA MS, J Sport Health Res, 2 (2010) 167. — 14. TUL M, LESKOŠEK B, KOVAČ M, Hacettepe Egitim Dergisi 30 (2015) 268. - 15. KOVAČ M, TUL M, LESKOŠEK B, Center for Educational Policy Studies Journal, 9 (2019) 103. doi:10.26529/ cepsj.662. - 16. NIEMINEN P, TAKIZAW K, GOULIMARIS D, SAKASHITA R, PE students' perception of the importance of the competencies of quality physical education teacher: A cross-cultural study. In: Proceedings (AIESEP 2008 World Congress, Sapporo, 2008). - 17. ROMERO CEREZO C, ZAGALAS SANCHEZ ML, ROMERO RODRIGUEZ MN, MARTINEZ LOPEZ E, Retos, 19 (2011) 62. doi:10.47197/retos.v0i19.34641. - 18. JOHNSON SM, KRAFT MA, PAPAY JP, Teach Coll Rec, 114 (2012) 1. doi:10.1177/016146811211401004. - 19. MA X, MACMILLAN RB, J Educ Res, 93 (1999) 39. doi:10.1080/00220679909597627. — 20. MÄKELÄ K, HIRVENSALO M, TPE, 72 (2015) 379. doi:10.18666/TPE-2015-V72I5-6186. - 21. TOROPOVA A, MYRBERG E, JOHANSSON S, Educ Rev, 73 (2021) 71. doi:10.1080/00131911.2019.1705247. — 22. NYSUT'S INNOVATION INITIATIVE, Teaching and Learning Conditions Matter. Key Considerations for Policymakers, https://www.nysut.org/ /media/files/nysut/resources/2015/september/whitepaperteachinglearning.pdf. - 23. ASSOCIATION FOR PHYSICAL EDUCATION, Phys Educ Matters, 10 (2015) 87. - 24. UNESCO, Quality Physical Education. Guidelines for Policy-Makers, https://en.unesco.org/inclusivepolicylab/sites/default/files/ learning/document/2017/1/231101E.pdf. — 25. HARDMAN K, Hum Mov, 9 (2008) 1. doi: 10.2478/v10038-008-0001-z. — 26. JURAK G, STREL J,
KOVAČ M, STARC G, LESKOŠEK B, BUČAR PAJEK M, FILIPČIČ T, KOLAR E, BEDNARIKJ, Analiza šolskih športnih dvoran z uporabniškega vidika. https://www.fsp.uni-lj.si/COBISS/Monografije/Telovadnice.pdf. 27. BLAŽEVIĆ I, BENASSI L, ŠTERPIN A, Econ Res-Ekon Istraz, 33 (2020) 1240. doi: org/10.1080/1331677X.2020.1719177. — 28. FERREIRA I, VAN DER HORST K, WENDEL-VOS W, KREMERS S, VAN LEHTE F, BRUG J, Obes Rev, 8 (2007) 129. doi: 10.1111/j.1467-789X.2006.00264.x. - 29. SALLIS JF, PROCHASKA JJ, TAYLOR WC, Med Sci Sports Exerc, 32 (2000) 963. doi: 10.1097/00005768-200005000-00014. - 30. MAHAR MT, Prev Med, 52 (2011) S60. doi: 10.1016/j.ypmed.2011.01.026. - 31. KOVAČ M, LESKOŠEK B, HADŽIĆ V, JURAK G, International Journal of Occupational Safety and Ergonomics, 19 (2013) 87. doi:10.1080/108035 48.2013.11076968. - 32. LEMOYNE J, LAURENCELLE L, LIRETTE M, TRUDEAU F, Appl Ergon, 38 (2007) 625. doi: 10.1016/j.apergo.2006.06.004. - 33. SANDMARK H, Occup Environ Med, 57 (2000) 673. doi: 10.1136/oem.57.10.673. - 34. VERHAGEN E, COLLARD D, PAW MCA, VAN MACHELEN V, Br J Sports Med, 43 (2009) 1031. doi:10.1136/ bjsm.2008.055483. - 35. KOVAČ M, MARKUN PUHAN N, LORENCI B, NOVAK L, PLANINŠEC J, HRASTAR I, PLETERŠEK K, MUHA V, Curriculum. Physical Education. Primary school programme. http://mizs. arhiv-spletisc.gov.si/fileadmin/mizs.gov.si/pageuploads/podrocje/os/prenovljeni_UN/UN_sportna_vzgoja.pdf. — 36. KOVAČ M, JURAK G, Izpeljava športne vzgoje (Faculty of Sport, Ljubljana, 2012). - 37. PISG LEGAL INFORMATION SYSTEM, Rules on norms and standards for the implementation of the primary school programme, http://www.pisrs.si/Pis.web/ pregledPredpisa?id=PRAV7973. -38 . PISG LEGAL INFORMATION SYSTEM, Rules on norms and standards for the implementation of educational programs in the field of secondary education, http://www.pisrs.si/Pis. web/pregledPredpisa?id=PRAV1024. -39 . MUJANOVIĆ Š, DOUPONA TOPIČ M, Šport, 57 (2009) 9. — 40. STIPEK DJ, BYLER P, Early Child Res Q, 12 (1997) 305. doi: org/10.1016/S0885-2006(97)90005-3. - 41. PISG LEGAL INFORMATION SYSTEM, Rules on the conditions for the establishment of public primary schools, public primary schools and institutions for the upbringing and education of children and adolescents with special needs and public music schools, http://www.pisrs.si/Pis.web/ pregledPredpisa?id=ODRE381. -42 . FULLER A, UNWIN L, J Educ Work, 16 (2003) 407. doi: 10.1080/1363908032000093012._43. TUNSCH C, BAHRAMI A, BOLLA C, BUI-XUÂN G, MORAL L, MIKULOVIC J, PIGEASSOU C, SCHRÖDER J, STARC G, VEROVNIK Z, Advancing key qualifications of disadvantaged young people through sporting activities (Zavod za šport Slovenije, 2005, Ljubljana). - 44. OECD, Creating Effective Teaching and Learning Environments. First Results from TALIS (OECD Publications, Paris, 2009).

\section{Kovač}

Faculty of Sport, University of Ljubljana, Gortanova ulica 22, 1000 Ljubljana, Slovenia

e-mail:Marjeta.Kovac@fsp.uni-lj.si 
SAMOPOIMANJE PREDMETNIH STRUČNIH KOMPETENCIJA SLOVENSKIH UČITELJA TJELESNE I ZDRAVSTVENE KULTURE U RAZLIČITIM RADNIM OKRUŽENJIMA

\section{S A Ž E T A K}

Ova je studija osmišljena kako bi se analizirale razlike u predmetnim kompetencijama slovenskih nastavnika tjelesne i zdravstvene kulture prema njihovom fizičkom radnom okruženju. Ukupan uzorak ispitanika čini 681 slovenskih nastavnika tjelesne i zdravstvene kulture koji su ocjenjivali svoje stručne predmetne kompetencije $(n=40)$ na četverostupanjskoj Likertovoj ljestvici i dva čimbenika svog fizičkog radnog okruženja (veličina sportskih objekata i njihova oprema). Razlike u samopercepciji o kompetencijama specifičnim za predmet između onih koji rade u dobrim uvjetima i onih koji rade u lošijim uvjetima identificirane su Mann-Whitneyjevim testom za nezavisne uzorke, a Cliffova delta korištena je za procjenu veličine razlika. Rezultati ukazuju kako na veću percepciju predmetnih kompetencija nastavnika tjelesne i zdravstvene kulture uglavnom utječe opremljenost sportskih objekata, a ne njihova veličina; stoga lokalne zajednice i država trebaju osigurati da sve škole imaju približno jednako dobro opremljene sportske objekte. 
